\title{
Protein Degradation in Extracts of Exponential and Stationary Phase Vibrio Cells
}

\author{
By N. G. CAR AND D. R. WOODS* \\ CSIR Applied Microbial Genetics Unit. Department of Microbiology, Unitersity of Cape Town. \\ Rondebosch 7700. South Africa
}

(Receiced 7 June 1984)

The degradation of the foreign protein $\left[{ }^{1+} \mathrm{C}\right]$ methyl apohaemoglobin $\left(\left[{ }^{1+} \mathrm{C}\right.\right.$-me]globin) was stimulated by ATP in cell-free extracts from exponential phase and shaken and standing stationary phase Vibrio cells. A marked stimulation by ATP of the degradation of $\left[{ }^{1+} \mathrm{C}\right.$-me]globin was observed with exponential phase cell extracts which were preincubated for $30 \mathrm{~min}$ at $30^{\circ} \mathrm{C}$. Maximum stimulation was obtained with $3 \mathrm{mM}-\mathrm{ATP}$ and optimum degradation was at $\mathrm{pH} 8.0$ 8.5. Preincubation of extracts from both types of stationary phase cells did not affect the degree of ATP stimulation. The amount of ATP stimulation of $\left[{ }^{4} \mathrm{C}\right.$-melglobin degradation by exponential phase extracts decreased markedly when the cells were starved in a growth limiting minimal medium before preparation of the cell extracts. In the exponential and both types of stationary phase extracts most of the activity was located in the cytoplasmic fractions. Although the periplasmic preparations contained a minor portion of the total activity, this activity showed a greater percentage stimulation by ATP. In the absence of ATP the specific proteolytic activities of the extracts from exponential and both types of stationary phase cells were similar. The proteolytic activities in all the cell extracts were inhibited to the same extent by phenylmethylsulphonyl fluoride, but the exponential and both types of stationary phase cell extracts were inhibited to different extents by EDTA and $p$-hydroxymercuribenzoate. The results suggest that the proteolytic systems responsible for the degradation of abnormal proteins are different in exponential and stationary phase Vibrio cells.

\section{INTRODUCTION}

Stationary phase cells of Vibrio strain 14 are novel and interesting in that they are able to support phage growth and provide an experimental system for studying regulation in non-sporulating stationary phase cells (Woods, 1976; Robb et al., 1977, 1978). Phage growth on stationary phase cells occurs in standing cultures but not in shaken (aerated) cultures. After shaking has ceased the small, non-flagellated cells present in shaken stationary phase cultures become large. flagellated rods which resemble exponential phase cells (Robb et al., 1980). Robb et al. (1980) suggested that the relatively high levels of protein synthesis in the small unhealthy cells from shaken stationary phase cultures may be due to non-specific and erroneous transcription. This could result in a 'sick' uncontrolled protein synthesis similar to that in relaxed mutants (Hall \& Gallant, 1972; Travers, 1976), and would result in the production of a high proportion of abnormal proteins in shaken stationary phase cells. Since bacterial and animal cells rapidly degrade proteins with abnormal conformations (Goldberg \& Dice, 1974), shaken stationary phase cells may have efficient proteolytic systems which hydrolyse abnormal proteins. In order to determine whether shaken stationary phase cells have an enhanced ability to degrade abnormal

Abbreviations: $\left[{ }^{1+} \mathrm{C}\right.$-me $]$ Globin, $\left[{ }^{1+} \mathrm{C}\right]$ methyl apohaemoglobin; PHMB, p-hydroxymercuribenzoate, sodium salt; PMSF, phenylmethylsulphonyl fluoride; TMKD buffer, Tris/HCl (50 mM, pH 8.0), $\mathrm{MgCl}_{2}(10 \mathrm{mM}), \mathrm{KCl}$ (10 mM), DTT (0.5 mM). 
proteins, we investigated the ability of extracts from shaken and standing stationary phase cells to degrade the foreign protein [ ${ }^{1+C} \mathrm{C}$-melglobin.

Previous studies with reticulocyte lysates have shown that [ ${ }^{14} \mathrm{C}$-melglobin is rapidly degraded by the same proteolytic system that hydrolyses analogue-containing or puromycyl polypeptides (Etlinger \& Goldberg, 1977). Murakami et al. (1979) reported that the degradative systems responsible for the hydrolysis of $\left[{ }^{1+} \mathrm{C}\right.$-melglobin and the disappearance of the small nonsense fragment of $\beta$-galactosidase, 545, were similar and concluded that this degradative system is responsible for the energy-dependent degradation of abnormal proteins in Escherichia coli. Since $\left[{ }^{1+} \mathrm{C}\right.$-melglobin has been shown to be a suitable substrate for the investigation of abnormal protein degradation in $E$. coli and other cells it was utilized in this study.

In $E$. coli the degradation of proteins is energy-dependent (Kowit $\&$ Goldberg, 1977) and protein degradation is stimulated by ATP in extracts of $E$. coli cells (Murakami et al., 1979). This ATP-stimulated proteolytic system in $E$. coli appears to be responsible for the energy-dependent degradation of abnormal proteins. Since ATP concentrations in shaking and standing stationary phase cells are lower than in exponential phase cells (Robb et al., 1980), we also investigated the effect of ATP on the hydrolysis of [ ${ }^{14} \mathrm{C}$-melglobin.

\section{METHODS}

Media. The tryptone broth of Thomson \& Woods (1974) was used for bacterial growth. Incubation was at $30^{\circ} \mathrm{C}$.

Bacteria. The strain previously isolated and classified as an Achromobacter strain 14 but recently reclassified as a Vibrio strain 14 was used (Robb et al., 1980).

Stationary phase cultures. Stationary phase cultures of Vibrio strain 14 were routinely prepared by growth in 1 litre tryptone broth in a 2 litre round flat-bottomed flask on a Gallenkamp rotary shaker at 150 r.p.m. for $3 \mathrm{~d}$ at $30^{\circ} \mathrm{C}$ (approximately $2 \times 10^{9} \mathrm{cells} \mathrm{ml}^{-1}$; Robb et al., 1978). The culture was then divided : aeration of one half was continued (shaken culture) while the other half was transferred to a I litre Schott blue capped bottle and incubated aerobically without shaking (standing culture). The conditions obtained after $24 \mathrm{~h}$ standing have been shown to be optimal for stationary phase phage growth (Robb et al., 1978). The levels of RNA and protein synthesis in the shaken and standing stationary phase cultures were determined and shown to be similar to those reported by Robb et al. (1980).

Starved exponential phase cells. Cells in exponential phase growth in tryptone broth were harvested and washed by centrifugation, resuspended in a prewarmed growth limiting minimal medium [Tris/HCl, $100 \mathrm{mM}, \mathbf{p H} 7.6$; $\mathrm{NaCl}, 0.4 \mathrm{~m} ; \mathrm{NH}_{4} \mathrm{SO}_{4}, 7.6 \mathrm{~mm} ; \mathrm{MgCl}_{2}, 0.4 \mathrm{~mm}$; sodium citrate, $1.6 \mathrm{~mm} ;$ glucose, $\left.0.03 \%(w / \mathrm{v})\right]$ and incubated with shaking.

Preparation of cell-free extracts. Exponential and stationary phase cultures were harvested and washed twice by centrifugation at $10000 \mathrm{~g}$ for $10 \mathrm{~min}$. The pellet of cells was frozen with liquid nitrogen and lysed by a modification of the method of Wickner et al. (1972). After thawing the pellet, the cells were suspended in $50 \mathrm{~mm}$ triethanolamine buffer (pH 8.0) containing $10 \%(\mathrm{w} / \mathrm{v})$ sucrose and $100 \mu \mathrm{g}$ lysozyme $\mathrm{ml}^{-1}(2 \mathrm{ml}$ buffer per $\mathrm{g}$ wet weight of cells) and incubated on ice for $30 \mathrm{~min}$. $\mathrm{KCl}(0.5 \mathrm{M})$ and $\beta$-mercaptoethanol (10 mM) were added and the lysed suspension was centrifuged at $30000 \mathrm{~g}$ for $30 \mathrm{~min}$ at $4^{\circ} \mathrm{C}$, and the supernatant was dialysed against TMKD buffer. Dialysed samples $(1 \mathrm{ml})$ were stored frozen in liquid nitrogen. Protein concentrations were determined by the method of Lowry using bovine serum albumin as a standard.

Preparation of radiolabelled substrates. Apohaemoglobin, prepared from bovine haemoglobin (Sigma) by the method of Yonetani (1967), was methylated with [ $\left.{ }^{14} \mathrm{C}\right]$ formaldehyde (Rice \& Means, 1971). The specific activity of the various preparations varied between 1 and $4 \times 10^{6}$ c.p.m. (mg protein) ${ }^{-1}$.

Protein degradation. The degradation of the labelled substrates was measured by a modification of the method of Murakami et al. (1979) at $30^{\circ} \mathrm{C}$ by incubating $100 \mu \mathrm{l} \mathrm{extract}\left(15 \mathrm{mg}\right.$ protein $\mathrm{ml}^{-1}$ ) with $10 \mu \mathrm{g}\left[{ }^{14} \mathrm{C}\right.$-melglobin (approximately $10^{+}$c.p.m.) in the presence or absence of nucleotides or inhibitors. Samples $(50 \mu \mathrm{l})$ were removed at timed intervals, mixed with $50 \mu \mathrm{l}$ bovine serum albumin $\left(30 \mathrm{mg} \mathrm{ml}^{-1}\right)$ as a carrier and diluted into $100 \mu \mathrm{l}$ cold TCA $(10 \%, w / v)$. After $30 \mathrm{~min}$ the samples were centrifuged in an Eppendorf microfuge model 5412 for $1 \mathrm{~min}$ and the acid-soluble radioactivity released from the globin was determined. The optimum pH for the proteolytic activity of the extracts was determined in reaction mixtures which contained: cell extract, $50 \mu \mathrm{l} ;\left[{ }^{14} \mathrm{C}\right.$-me $]$ globin in saline, $25 \mu \mathrm{l}$; and Tris/saline buffer [Tris/ $/ \mathrm{HCl}, 200 \mathrm{~mm}$; sodium chloride $0.85 \%(\mathrm{w} / \mathrm{v})], 50 \mu \mathrm{l}$. The Tris/saline buffer was adjusted with acetic acid for $\mathrm{pH}$ values of $\mathbf{7 . 0}$ and below. The effects of the following protease inhibitors were determined; EDT A, o-phenanthroline, PHMB and PMSF at the concentrations given in Table 3. An appropriate dilution of the inhibitor $(10 \mu \mathrm{l})$ was mixed with the cell-free extract $(50 \mu)$ for $5 \mathrm{~min}$ at $30^{\circ} \mathrm{C}$ before the addition of the labelled substrate $(65 \mu \mathrm{l})$. The acid-soluble radioactivity released after $1 \mathrm{~h}$ at $30^{\circ} \mathrm{C}$ was assayed. PMSF was dissolved in dimethyl sulphoxide. Control experiments indicated that dimethyl sulphoxide had no effect on the protease activities of the cell extracts. 
Cellular localization of proteases. Cytoplasmic and periplasmic proteolytic extracts were prepared by a modification of the method of Kaback (1971). Cells were harvested and washed by centrifugation and then resuspended in buffer [Tris/HC] $30 \mathrm{mM}, \mathrm{pH} 8.0$; sucrose, $20 \%(w / v) ;$ EDTA, $10 \mathrm{~mm}$; lysozyme, $100 \mu \mathrm{g} \mathrm{ml}^{-1}$ ] and incubated on ice for $1 \mathrm{~h}$. The supernatant obtained after centrifugation at $16000 \mathrm{~g}$ for $10 \mathrm{~min}$ was the periplasmic fraction. The pellet was resuspended in buffer (triethanolamine, $50 \mathrm{mM}, \mathrm{pH} 8.0 ;$ sucrose, $10 \%$ (w/v); mercaptoethanol, $10 \mathrm{~mm}: \mathrm{MgSO}_{4}, 5 \mathrm{mM} ; \mathrm{KCl}, 0.5 \mathrm{M}$ : DNAase, $5 \mu \mathrm{g} \mathrm{ml} \mathrm{I}^{-1}$ ) and incubated on ice for $30 \mathrm{~min}$, frozen in liquid nitrogen, and then thawed at $10^{\circ} \mathrm{C}$. The supernatant collected after centrifugation at $40000_{8}$ for 45 min was the cytoplasmic fraction. The fractions were dialysed for $12 \mathrm{~h}$ at $4^{\circ} \mathrm{C}$ against TMKD buffer before determination of the proteolytic activities.

\section{RESULTS}

\section{Proteolytic activities of cell extracts}

The protein concentrations of the dialysed cell-free extracts from exponential and standing stationary phase cells were similar but the equivalent extracts from the shaken stationary phase cells were routinely less than half that of the other extracts. Proteolytic activities of the extracts against $\left[{ }^{14} \mathrm{C}\right.$-me]globin were always determined at the same protein concentrations and were shown to be very similar without the addition of ATP (Table 1). The proteolytic activities of the extracts were stable for at least one month at $-20^{\circ} \mathrm{C}$ and for at least $5 \mathrm{~d}$ at $4{ }^{\circ} \mathrm{C}$.

\section{Effect of ATP on proteolytic activities}

The degradation of $\left[{ }^{14} \mathrm{C}\right.$-melglobin by dialysed cell-free extracts from exponential phase and shaken and standing stationary phase cells was only slightly stimulated by ATP (Table 2). Preincubation of the extracts from both types of stationary phase cells for $30 \mathrm{~min}$ at $30^{\circ} \mathrm{C}$ did not markedly affect the degree of ATP stimulation (Table 2). However, preincubation of exponential phase cell extracts resulted in a marked stimulation of proteolytic activity by ATP (approximately 2.5- to 5-fold at $3 \mathrm{mM}-\mathrm{ATP}$; Fig. 1). Although the experiments were repeated at least 20 times under identical conditions, it was not possible to reduce the variation in ATP stimulation between the different preincubated exponential phase extracts. The proteolytic

Table 1. Specific activities of the dialysed cell-free extracts

The cell-free extracts were diluted to the same protein concentration $\left(10 \mathrm{mg} \mathrm{ml}^{-1}\right)$ and the activities determined without the addition of ATP. The activities shown are means of 4 experiments, $\pm S D$.

$\begin{array}{lc}\text { Cell-free extract } & \begin{array}{c}\text { Specific activity } \\ {[\mu \mathrm{g} \text { globin hydrolysed }} \\ \left.\mathrm{min}^{-1}(\mathrm{mg} \text { protein })^{-1}\right]\end{array} \\ \text { Exponential } & 0.57 \pm 0.02 \\ \text { Shaken stationary } & 0.68 \pm 0.08 \\ \text { Standing stationary } & 0.62 \pm 0.03\end{array}$

Table 2. Effect of preincubation on the degradation of $\left[{ }^{14} \mathrm{C}\right.$-me $] \mathrm{globin}$ by extracts from exponential and stationary phase Vibrio cells

Dialysed cell extracts were preincubated without $A T P$ at $30^{\circ} \mathrm{C}$ for $30 \mathrm{~min}$ before the addition of substrate with or without ATP ( $3 \mathrm{~mm})$. The results are expressed relative to the dialysed extract assayed without preincubation or the addition of ATP, for which the specific activity was $0.57 \mu \mathrm{g} g$ lobin hydrolysed $\mathrm{min}^{-1}$ (mg protein) ${ }^{-1}$. The values given are the means of six independent experiments and the amount of variation was $<10 \%$ from the mean.

\begin{tabular}{|c|c|c|c|c|}
\hline \multirow[b]{2}{*}{ Cell-free extract } & \multicolumn{2}{|c|}{$\begin{array}{l}\text { Dialysed extract, } \\
\text { not preincubated }\end{array}$} & \multicolumn{2}{|c|}{$\begin{array}{l}\text { Dialysed extract, } \\
\text { preincubated }\end{array}$} \\
\hline & $-A T P$ & + ATP & $-\mathbf{A T P}$ & + ATP \\
\hline Exponential & I & 1.76 & 1.07 & 3.70 \\
\hline Shaken stationary & 1 & 1.73 & 1.29 & 1.63 \\
\hline Standing stationary & 1 & $1 \cdot 70$ & 1.33 & 1.50 \\
\hline
\end{tabular}




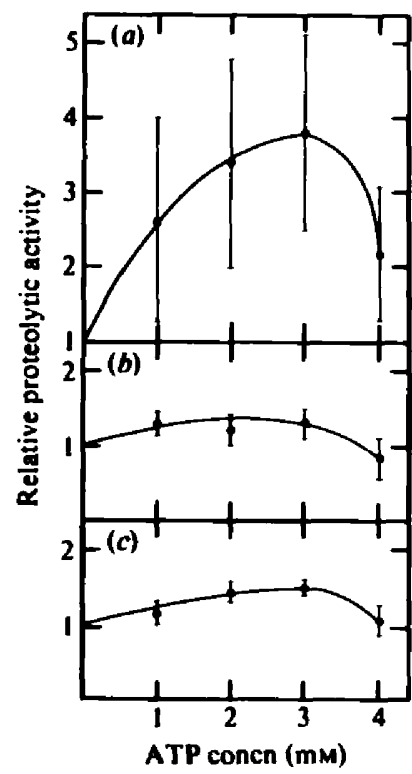

Fig. I

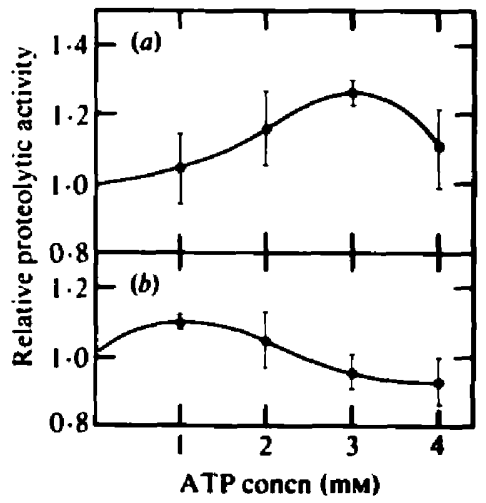

Fig. 2

Fig. I. Effect of ATP on the degradation of [ ${ }^{14} \mathrm{C}$-melglobin by exponential and stationary phase Vibrio cell-free extracts. Preincubated cell extracts from exponential phase cells $(a)$; dialysed cell extracts from shaken $(b)$ and standing $(c)$ stationary phase cells. The points represent means from 20 experiments for the exponential phase extract and 5 experiments for the stationary phase extracts; the bars represent ranges of results.

Fig. 2. Effect of ATP on the degradation of $\left({ }^{4} \mathrm{C}\right.$-melglobin by preincubated cell-free extracts from exponential cells resuspended in a growth limiting minimal medium. Cells were starved for $30(a)$ and 90 (b) $\mathrm{min}$ before preparation of the cell extracts. The points represent means from 3 experiments; the bars represent ranges of results.

activities of the dialysed or preincubated extracts from both types of stationary phase cells and dialysed extracts from exponential phase cells showed less variation in ATP stimulation and were all within $20 \%$ of the values given. ATP stimulation of preincubated extracts from exponential phase cells was very sensitive to the method of cell breakage. When less gentle methods of cell lysis were used (several passages through a French pressure cell at $10.3 \mathrm{MPa}$ ) ATP stimulation of dialysed or preincubated extracts from exponential phase cells was not observed. Maximum protein degradation was obtained with $3 \mathrm{mM}-A$ TP. The addition of GTP (1 and $2 \mathrm{mM})$ had no significant effect on the degradation of $\left[{ }^{14} \mathrm{C}\right.$-me]globin. In exponential cell extracts, GTP ( 1 and $2 \mathrm{mM}$ ) caused a 15 and $13 \%$ decrease, respectively, in the proteolytic activities. The shaken and standing stationary phase extracts containing 1 and $2 \mathrm{~mm}$-GTP showed $<7 \%$ increase in proteolytic activity.

Although the proteolytic activities of the dialysed exponential and stationary phase extracts were stable at $-20^{\circ} \mathrm{C}$ and $4^{\circ} \mathrm{C}$ for considerable periods, the amount of ATP stimulation decreased on storage.

The amount of ATP stimulation of $\left[{ }^{14} \mathrm{C}\right.$-melglobin degradation by preincubated exponential phase cell-free extracts decreased markedly when the cells were starved in the growth-limiting minimal medium before preparation of the cell extracts (Fig. 2).

\section{Effect of $\mathrm{pH}$ on proteolytic activities}

The proteolytic activities of the exponential and the stationary phase extracts had a broad $\mathrm{pH}$ optimum between pH 7.0 and 9.5 but with marked inhibition below pH 7.0. 
Table 3. Cellular localization of proteolytic activities from exponential and stationary phase Vibrio cells

Periplasmic and cytoplasmic cell-free extracts were prepared from exponential and both types of stationary phase cells and assayed for proteolytic activity with and without the addition of ATP (3 mM). The data from one of four independent experiments are given. The results from all the experiments were within $7 \%$ of the values given.

\begin{tabular}{|c|c|c|c|}
\hline \multirow[b]{2}{*}{ Cell-free extract } & \multicolumn{2}{|c|}{ Activity (c.p.m.) } & \multirow{2}{*}{$\begin{array}{c}\text { Stimulation } \\
(\%)\end{array}$} \\
\hline & - ATP & + ATP & \\
\hline $\begin{array}{l}\text { Periplasmic } \\
\text { Exponential } \\
\text { Shaken stationary } \\
\text { Standing stationary }\end{array}$ & $\begin{array}{l}237 \\
430 \\
670\end{array}$ & $\begin{array}{l}349 \\
523 \\
769\end{array}$ & $\begin{array}{l}47 \\
22 \\
14\end{array}$ \\
\hline $\begin{array}{l}\text { Cytoplasmic } \\
\text { Exponential } \\
\text { Shaken stationary } \\
\text { Standing stationary }\end{array}$ & $\begin{array}{l}2396 \\
2175 \\
2261\end{array}$ & $\begin{array}{l}2785 \\
2516 \\
2311\end{array}$ & $\begin{array}{r}16 \\
16 \\
2\end{array}$ \\
\hline
\end{tabular}

Table 4. Effect of inhibitors on the degradation of $\left[{ }^{14} \mathrm{C}\right.$-me $]$ globin by exponential and stationary phase Vibrio cell extracts

Proteolytic activities were determined without the addition of ATP. The values given are the average of five independent experiments and the amount of variation was $<8 \%$ from the mean.

\begin{tabular}{lcccc}
\cline { 3 - 4 } Inhibitor & $\begin{array}{c}\text { Concn } \\
\text { (mm) }\end{array}$ & $\begin{array}{c}\text { Exponential } \\
\text { phase }\end{array}$ & $\begin{array}{c}\text { Shaken } \\
\text { stationary } \\
\text { phase }\end{array}$ & $\begin{array}{c}\text { Standing } \\
\text { stationary } \\
\text { phase }\end{array}$ \\
EDTA & 10 & 94 & 80 & 84 \\
& 5 & 91 & 79 & 84 \\
o-Phenanthroline & 1 & 0 & 54 & 25 \\
PMSF & 0.5 & 51 & 76 & 66 \\
PHMB & 5 & 80 & 83 & 65 \\
& 5 & 35 & 69 & 67 \\
& 1 & 5 & 70 & 66 \\
& $0 \cdot 15$ & 0 & 72 & 73
\end{tabular}

\section{Cellular localization of proteolytic activities}

The proteolytic activities of periplasmic and cytoplasmic extracts were determined (Table 3 ). In all the exponential and stationary phase extracts most of the activity was located in the cytoplasmic fractions. Although the periplasmic preparations contained, in each case, a minor proportion of the total activity, they showed a greater percentage stimulation by ATP. Preincubation did not affect the proteolytic activities of the various fractions in the presence or absence of ATP.

\section{Effect of protease inhibitors on proteolytic activities}

The effects of various protease inhibitors were studied in the absence of ATP (Table 4). The proteolytic activities of the exponential and stationary phase cell extracts were all markedly inhibited by the metal chelating agents EDTA and $o$-phenanthroline. The extracts were more sensitive to o-phenanthroline (which preferentially chelates divalent cations other than $\mathrm{Ca}^{2+}$ ) than to EDTA. The stationary phase cell extracts were more sensitive to EDTA than the exponential phase cell extracts. The serine protease inhibitor PMSF inhibited all the extracts to approximately the same extent. The thiol group inhibitor PHMB caused a $70 \%$ inhibition of the activities of the stationary phase cell extracts over a wide range of PHMB concentrations. The inhibition of the activities of the exponential phase cell extracts was markedly less sensitive to PHMB and the inhibition decreased with a decrease in PHMB concentration. 


\section{DISCUSSION}

The ability of exponential and stationary phase cell extracts to degrade the foreign protein $\left[{ }^{14} \mathrm{C}\right.$-me]globin was affected to different extents by ATP and preincubation. Although all the cell extracts were inhibited to the same extent by the serine protease inhibitor PMSF, the exponential and stationary phase extracts were inhibited to different extents by EDTA and PHMB. These results suggest that the proteolytic systems responsible for abnormal protein degradation in exponential and stationary phase Vibrio cells are different.

Although maximum stimulation of proteolytic activity by ATP in cell extracts from exponential Vibrio and $E$. coli (Murakami et al., 1979) cells was obtained with 3 mM-ATP, the Vibrio extracts had to be preincubated before ATP stimulation was observed. In $E$. coli the stimulatory effect of ATP was lost after preincubation (Murakami et al., 1979). The optimum pH for proteolytic activity in extracts from exponential Vibrio and $E$. coli cells was similar (pH 8.0 to 8.5). The bulk of Vibrio proteolytic activity was cytoplasmic; however, the periplasmic proteolytic activity showed a greater stimulation by ATP.

The amount of ATP stimulation varied considerably between preincubated extracts prepared under identical conditions from exponential phase cells. ATP stimulation was markedly affected by the method of cell breakage and this could play a role in the variation between different experiments. The amount of variation obtained in similar experiments with $E$. coli cell extracts by Murakami et al. (1979) was not indicated. In a recent study by Liu et al. (1984) on the degradation of abnormal proteins by extracts from yeast, similar variations in proteolytic activities were reported.

The shaken and standing stationary phase proteolytic systems responsible for the degradation of the foreign protein [ ${ }^{14} \mathrm{C}$-melglobin were relatively insensitive to ATP stimulation when compared with exponential extracts. This suggests that these stationary phase proteolytic systems in Vibrio are different from the ATP-stimulated proteolytic system in $E$. coli which appears to be responsible for the energy-dependent degradation of abnormal proteins (Murakami et al., 1979). Robb et al. (1980) reported that stationary phase Vibrio cells contain less ATP than exponential phase cells (20 to $57 \%$ less). St John \& Goldberg (1978) reported that a moderate inhibition of energy metabolism ( 30 to $50 \%$ reduction) accelerated the breakdown of normal cell proteins in a similar fashion to starvation, but a drastic reduction of ATP levels $(80 \%$ reduction) inhibited the degradation of all cell proteins. Starvation of exponential phase Vibrio cells markedly reduced the amount of ATP-stimulated proteolytic activity and the responses of extracts from starved cells to ATP were similar to those obtained with extracts from stationary phase cells.

There was little difference in the rate of proteolysis of the shaken and standing stationary phase extracts when measured against the foreign protein $\left[{ }^{14} \mathrm{C}\right.$-me]globin. This is interesting as the amount of protein synthesis in the apparently 'healthy' standing stationary phase cells never exceeded $4 \%$ of that in the small 'sick' standing stationary phase cells (Robb et al., 1980). Murakami et al. (1979) were able to demonstrate considerable differences (two- to threefold) between proteolysis of $\left[{ }^{14} \mathrm{C}\right.$-melglobin in extracts of E. coli $\mathrm{Deg}^{+}$and $\mathrm{Deg}^{-}$strains. Greater proteolysis of this foreign protein in extracts of the $\mathrm{Deg}^{+}$strain correlated with the more rapid breakdown of abnormal proteins in these cells and suggested that proteolysis in these preparations was related to breakdown in vivo. The failure to demonstrate differences in the specific activities of the shaken and standing stationary phase extracts suggests there is no general enhancement of proteolytic activities for the degradation of abnormal proteins in 'sick' shaken stationary phase cells.

\section{REFERENCES}

EtLinger, J. \& Goldaero, A. L. (1977). A soluble ATP-dependent proteolytic system responsible for the degradation of abnormal proteins in reticulocytes. Proceedings of the National Academy of Sciences of the United States of America 74, 54-58.

GOLDBERo, A. L. \& DiCE, J. F. (1974). Intracellular protein degradation in mammalian and bacterial cells. Annual Review of Biochemistry 43, 835-869.
Hall, B. \& Gallant, J. (1972). Defective translation in $\mathrm{RC}^{-}$cells. Nature New Biology 237, 131-135.

KAвасK, H. R. (1971). Bacterial membranes. In Enzyme Purification and Related Techniques XXII, pp. 99-120. Edited by W. B. Jakoby. New York: Academic Press.

KowIT, J. D. \& GoldBero, A. L. (1977). Intermediate steps in the degradation of a specific abnormal 
protein in Escherichia coli. Journal of Biological Chemistry 252, 8350-8357.

LiU, C.-J., Chopra, A. K., Strnadova, M. \& Chuloupxa, J. (1984). Degradation of abnormal proteins in growing yeast. FEMS Microbiology Letters 21, 313-317.

Muraxami, K., Voellmy, R. \& Goldberg, A. L. (1979). Protein degradation is stimulated by ATP in extracts of Escherichia coli. Journal of Biological Chemistry 254, 8194-8200.

Rice, R. H. \& MeANS, G. E. (1971). Radioactive labelling of proteins in vitro. Journal of Biological Chemistry 246, 831-832.

Robs, S. M., WoOds, D. R., Robs, F. T. \& Struthers, J. K. (1977). Rifampicin-resistant mutant supporting bacteriophage growth on stationary phase Achromobacter cells. Journal of General Virology 35 . 117-123.

Rosb, S. M., Woods, D. R. \& Robs, F. T. (1978). Phage growth characteristics on stationary phase Achromobacter cells. Journal of General Virology 41 , 265-272.

RoBs, S. M., RoBb, F. T. \& WoOds, D. R. (1980). Physiological and morphological characteristics of stationary phase Vibrio cells able to support phage growth. Journal of General Microbiology 119, 405412.

St John, A. C. \& Goldberg, A. L. (1978). Effects of reduced energy production on protein degradation, guanosine tetraphosphate, and RNA synthesis in Escherichia coli. Journal of Biological Chemistry 253. 2705-2711.

Thomson, J. A. \& Woods, D. R. (1974). Bacteriophages and cryptic lysogeny in Achromobacter. Journal of General Virology 22, 153-157.

TrAvers, A. A. (1976). RNA polymerase specificity and the control of growth. Nature, London 263, 641646.

WICKNER, W., BRUTLAG, D., SChEKMAN, R. \& KorNBERG, A. (1972). RNA synthesis initiates in vitro conversion of M13 DNA to its replicative form. Proceedings of the National Academy of Sciences of the United States of America 69, 965-969.

Woods, D. R. (1976). Bacteriophage growth on stationary phase Achromobacter cells. Journal of General Virology 32, 45-50.

YONETANI, T. (1967). Crystalline apo- and reconstituted holoenzymes. Journal of Biological Chemistry 242. 5008-5013. 